\title{
Pola bakteri aerob yang berpotensi menyebabkan infeksi nosokomial di ruangan Instalasi Rawat Darurat Obstetri dan Ginekologi (IRDO) RSUP Prof. Dr. R. D. Kandou Manado
}

\author{
${ }^{1}$ Rizka Matoka \\ ${ }^{2}$ Olivia Waworuntu \\ ${ }^{2}$ Fredine Rares
}

\author{
${ }^{1}$ Kandidat Skripsi Fakultas Kedokteran Universitas Sam Ratulangi Manado \\ ${ }^{2}$ Bagian Mikrobiologi Fakultas Kedokteran Universitas Sam Ratulangi Manado \\ Email: riskamatoka04@gmail.com
}

\begin{abstract}
Nosocomial infection or Health-care Associated Infection (HAIs) according to the WHO in 2011 are infection to patient acquired during a hospital, after $\geq 48$ hours and $\leq 30$ days after out of the hospital. Factor of infection can be differentiated between patients, nurses, doctors, hospital employed, hospital environment and patient visitor or family. The purpose to know the pattern of aerobic bacteria that could potentially to involve nosocomial infection in the Emergency room of Obstetric and Gynecology (IRDO) Prof. Dr. R. D. Kandou Manado. Type a descriptive observational research with cross sectional study approach. The sampling on the walls, floors, medical equipment, room furniture and the air in the IRDO Prof. Dr. R. D. Kandou Hospital Manado. The results of the 27 samples found bacteria Bacillus sp.(46,55\%), Staphylococcus sp. (18,97\%), Streptococcus sp. (10,34\%), Klebsiella pneumoniae $(8,62 \%)$, Enterobacter aerogenes, Serratia liquefaciens, Enterobacter cloacea, proteus sp. $(3,45 \%)$, Neisseria sp. $(1,72 \%)$.Conclusion: The most aerobic bacteria in the Emergency room of Obstetric and Gynecology (IRDO) Prof. Dr. R. D. Kandou Manado is Bacillus sp.(46,55\%).

Keywords: Emergency Obstetric and Gynecology, nosocomial infection, aerobic bacteria.
\end{abstract}

\begin{abstract}
Abstrak: Instalasi Rawat Darurat Obstetri dan Ginekologi (IRDO) adalah suatu instalasi penanggulangan awal penderita rawat darurat untuk mencegah kematian, dalam menangani kesehatan reproduksi wanita saat tidak hamil ataupun pada saat hamil, persalinan, dan nifas. Infeksi nosokomial atau Health-care Associated Infection (HAIs) menurut WHO 2011 merupakan infeksi yang didapat pasien selama di rumah sakit, setelah $\geq 48$ jam dan $\leq 30$ hari setelah keluar dari rumah sakit. Faktor terjadinya infeksi bisa dibebakan antar pasien, perawat, dokter, karyawan rumah sakit, lingkungan rumah sakit, dan pengunjung atau keluarga pasien. Tujuan untuk mengetahui pola bakteri aerob yang berpotensi menyebabkan infeksi nosokomial pada ruangan Instalasi Rawat Darurat Obstetri dan Ginekologi (IRDO) RSUP Prof. Dr. R. D. Kandou Manado. Jenis penelitian deskriptif observational dengan pendekatan studi cross sectional. Pengambilan sampel pada dinding, lantai, peralatan medis, perabotan ruangan, udara di ruangan Instalasi Rawat Darurat Obstetri dan Ginekologi (IRDO) RSUP Prof. Dr. R. D. Kandou Manado. Hasil penelitian dari 27 sampel ditemukan bakteri Bacillus sp.(46,55\%), Staphylococcus sp. (18,97\%), Streptococcus sp. (10,34\%), Klebsiella pneumoniae (8,62\%), Enterobacter aerogenes, Serratia liquefaciens, Enterobacter cloacea, proteus sp. (3,45\%), Neisseria sp. (1,72\%). Simpulan: Bakteri aerob di ruangan Instalasi Rawat Darurat Obstetri dan Ginekologi (IRDO) RSUP Prof. Dr. R. D. Kandou Manado yang terbanyak ialah Bacillus sp. $(46,55 \%)$.
\end{abstract}

Kata kunci: Instalasi Rawat Darurat Obstetri dan Ginekologi (IRDO), Infeksi nosokomial, bakteri aerob 
Rumah sakit adalah salah satu bagian sistem pelayanan kesehatan yang secara garis besar memberikan pelayanan kesehatan untuk masyarakat berupa pelayanan medik, pelayanan penunjang medik, rehabilitasi medik, dan pelayanan perawatan. Di dalam sistem pelayanan rumah sakit terdapat unit-unit, dimana unit tersebut dilaksanakan melalui unit rawat darurat, unit rawat jalan, dan unit rawat inap. ${ }^{1}$ Dalam unit-unit ini juga terdapat sub unit contohnya dalam unit rawat darurat terdapat 4 sub unit, yaitu Instalasi Rawat Darurat Anak (IRDA), Instalasi Rawat Darurat Bedah (IRDB), Instalasi Rawat Darurat Medik (IRDM), dan Instalasi Rawat Darurat Obstetri dan Ginekologi (IRDO).

Instalasi Rawat Darurat Obstetri dan Ginekologi (IRDO) adalah suatu instalasi yang memberikan pelayanan penanggulangan awal penderita rawat darurat untuk mencegah terjadinya suatu kematian, ${ }^{2}$ dalam menangani pelayanan kesehatan wanita yang berhubungan dengan kesehatan reproduksinya saat tidak hamil ataupun pada saat hamil, persalinan, dan nifas. ${ }^{3}$

Pada umumnya orang datang ke rumah sakit untuk mencari kesembuhan, namun tanpa disadari rumah sakit juga merupakan sumber dari berbagai penyakit yang berasal dari penderita, petugas kesehatan, staf yang ada di rumah sakit, maupun dari pengunjung yang bersifat karier. Kuman penyakit ini dapat hidup dan berkembang di lingkungan rumah sakit, seperti udara, air, lantai, makanan, dan peralatan medis maupun non medis. ${ }^{4}$ Jadi infeksi yang mengenai seseorang yang berhubungan dengan rumah sakit akibat pengaruh dari lingkungan rumah sakit disebut dengan infeksi nosokomial. ${ }^{5}$ Istilah infeksi nosokomial saat ini banyak dikenal sebagai Hospital Acquired Infection (HAIs), ${ }^{6}$ dan bahkan sekarang orang-orang juga mengenal HAIs adalah kepanjangan dari Healthcare Associated Infection. Menurut World Health Organization (WHO) 2011 HAIs merupakan infeksi yang didapat pasien selama menjalani prosedur perawatan dan tindakan medis di pelayanan kesehatan setelah $\geq 48$ jam dan setelah $\leq 30$ hari setelah keluar dari fasilitas pelayanan kesehatan. $^{7}$

Kejadian terbanyak infeksi nosokomial terdapat di negara miskin dan negara yang sedang berkembang, karena penyakitpenyakit infeksi masih menjadi penyebab utamanya. Suatu penelitian yang dilakukan oleh WHO tahun 2006 menunjukkan bahwa sekitar $8,7 \%$ dari 55 rumah sakit pada 14 negara di Eropa, Timur Tengah, Asia Tenggara, dan Pasifik terdapat infeksi nosokomial, dan khususnya di Asia Tenggara sebanyak $10 \% .^{5}$

Dari hasil penelitian yang dilakukan di Instalasi Rawat Khusus RSUP Dr. Wahidin Sudirohusodo Makassar mengenai pola kuman yang terdapat di ICU, dengan pengambilan sampel air pada 3 titik di masing-masing Instalasi Central Operating Theatre (COT), Operatie Kamer Instalasi Rawat Darurat (OK IRD), dan Intensive Care Unit (ICU) ditemukan Klebsiella Pneumonia (30\%), E.coli (20\%), Alkaligenes faecalis (20\%), Enterobacter aglomerans (10\%), Proteus mirabilis (10\%), dan Providencia alkalifaciens $(10 \%){ }^{8}$ Penelitian lain dilakukan di BLU RSUP Prof. Dr. R. D. Kandou Manado pada kamar bersalin ditemukan bakteri terbanyak yaitu Bacillus subthilis, dimana ditemuakan sebanyak 15 sampel yang berasal dari dinding 3 sampel (37,5\%), lantai 2 sampel (25\%), tempat tidur 2 sampel (20\%), udara 7 sampel $(77,78 \%)$, serta selang tabung $\mathrm{O}_{2} 1$ sampel $(50 \%){ }^{9}$

Tempat penanganan pertama untuk pasien obstetri dan ginekologi adalah IRDO. Dalam praktiknya sebagai tempat penangan pertama pasti tidak lepas dengan adanya mikroorganisme yang tidak dapat kita lihat dengan kasat mata, misalnya melalui cairan tubuh yaitu darah dan cairan ketuban yang terdapat di tempat tidur, lantai atau bahkan bisa terkontaminasi dengan udara sekitar, dan juga dari peralatan medis yang digunakan untuk membantu melakukan tindakan medis khusunya dalam melakukan tindakan kuretase dan lain-lain. 
WHO memperkirakan kira-kira 210 juta wanita hamil setiap tahun dan 529.000 diantaranya meninggal karena komplikasi. Penyebab tersering kematian ibu terjadi pada periode post-partum, sepsis, dan perdarahan, yang biasanya disebabkan oleh flora endogen mikroorganisme yang ada dalam saluran genital. Beberapa mikroorganisme yang bersifat patogenik yang berada dalam saluran genital diantaranya Escherichia coli, Staphylococcus aureus, Proteus miribilis, Klebsiela pneumonia. ${ }^{10}$

Berdasarkan uraian yang telah dijelaskan maka peneliti tertarik untuk melakukan penelitian tentang pemeriksaan pola bakteri aerob yang berpotensi menyebabkan infeksi nosokomial di ruangan IRDO RSUP Prof. Dr. R. D. Kandou Manado.

\section{METODE PENELITIAN}

Penelitian ini merupakan penelitian deskriptif observational dengan pendekatan studi cross sectional untuk menilai pola bakteri aerob penyebab infeksi nosokomial di ruangan IRDO RSUP Prof. Dr. R. D. Kandou Manado, yang dilakukan pada bulan Aguatus - November 2016. Tempat pengambilan sampel dilakukan di ruangan IRDO RSUP Prof. Dr. R. D. Kandou Manado. Isolasi dan identifikasi bakteri dilakukan di Laboratorium Mikrobiologi Fakultas Kedokteran Universitas Sam Ratulangi Manado. Sampel penelitian diambil masing-masing pada dinding, lantai, udara, perabotan ruangan dan peralatan medis di ruangan IRDO RSUP Prof. Dr. R. D. Kandou Manado.

\section{HASIL PENELITIAN}

Sampel penelitian sebanyak 27 sampel diambil dari dinding, lantai, tempat tidur, perabotan ruangan udara dan peralatan medis di IRDO. Total media agar yang digunakan adalah 81 media agar. Identifikasi sampel dilakukan di Laboratorium Mikrobiologi Fakultas Kedokteran Unsrat Manado yaitu dengan pewarnaan Gram dan Uji biokimia IMViC.
Tabel 1. Distribusi Pengambilan sampel

\begin{tabular}{lcc}
\hline Kategori & Sampel & $\begin{array}{c}\text { Jumlah } \\
\text { Sampel }\end{array}$ \\
\hline Ruang & Dinding & 4 \\
Perawatan & Lantai & 5 \\
Perabotan & Tempat Tidur & 1 \\
Ruangan & Pegangan Pintu & 1 \\
Peralatan & USG & 1 \\
Medis & & \\
Udara & Pagi & 5 \\
& Siang & 5 \\
& Sore & 5 \\
Total & & $\mathbf{2 7}$ \\
\hline
\end{tabular}

Berdasarkan pertumbuhan bakteri pada media isolasi agar Mac Conkey, agar Nutrient, dan agar Darah maka hasil penelitian dapat dikelompokkan dalam Tabel 2. Dari 81 media agar yang digunakan didapatkan pertumbuhan bakteri yang ada pada media agar berjumlah 58 media agar, dan yang tidak ada pertumbuhannya berjumlah 23 .

Tabel 3 menunjukkan bahwa bakteri yang berbentuk bulat berjumlah 19, dan bakteri yang berbentuk batang berjumlah 39.

Tabel 2. Distribusi Pertumbuhan Bakteri

\begin{tabular}{lcccccc}
\hline & \multicolumn{5}{c}{ Media isolasi } \\
& \multicolumn{7}{c}{ Perbenihan } & \multicolumn{5}{c}{ Persentase (\%) } \\
\cline { 2 - 7 } & \multicolumn{3}{c}{ Jumlah } & & & \\
& NA & MC & AD & NA & MC & AD \\
& & & & & & \\
\hline Ada & 26 & 9 & 23 & 96,30 & 33,33 & 85,19 \\
Tidak Ada & 1 & 18 & 4 & 3,70 & 66,67 & 14,81 \\
Total & $\mathbf{2 7}$ & $\mathbf{2 7}$ & $\mathbf{7}$ & $\mathbf{1 0 0}$ & $\mathbf{1 0 0}$ & $\mathbf{1 0 0}$
\end{tabular}

Keterangan : NA (Nutrient Agar), MC (Agar Mac Conkey), AD (Agar Darah)

Tabel 3. Hasil Identifikasi Mikroorganisme Berdasarkan Pengecatan Gram

\begin{tabular}{|c|c|c|c|c|c|c|}
\hline \multirow{3}{*}{$\begin{array}{c}\text { Hasil } \\
\text { Pewarnaan } \\
\text { Gram }\end{array}$} & \multicolumn{4}{|c|}{ Bentuk } & \multirow{2}{*}{\multicolumn{2}{|c|}{ Total }} \\
\hline & \multicolumn{2}{|c|}{$\begin{array}{l}\text { Bulat/ } \\
\text { Coccus }\end{array}$} & \multicolumn{2}{|c|}{$\begin{array}{c}\text { Batang/ } \\
\text { Basil }\end{array}$} & & \\
\hline & $\bar{n}$ & $(\%)$ & $\mathrm{n}$ & $(\%)$ & $\mathbf{n}$ & $(\%)$ \\
\hline $\begin{array}{l}\text { Bakteri Gram } \\
\text { positif }\end{array}$ & 17 & 38,64 & 27 & 61,36 & 44 & 100 \\
\hline $\begin{array}{l}\text { Bakteri Gram } \\
\text { negatif }\end{array}$ & 2 & 14,28 & 12 & 85,71 & 14 & 100 \\
\hline
\end{tabular}

Ket: jumlah (n), persentase (\%) 
Tabel 4 menunjukkan bahwa pada agar Mac Conkey tidak ditumbuhi bakteri Gram positif, hal ini disebabkan karena bakteri Gram positif tidak bisa tumbuh pada agar Mac Conkey, begitu juga dengan agar Darah yang tidak ditumbuhi oleh bakteri Gram negatif, karena bakteri ini tidak bisa tumbuh pada agar darah. Berbeda dengan agar Nutrient yang ditumbuhi oleh bakteri Gram Positif dan Gram negatif, karena memang pada agar ini bisa ditumbuhi oleh kedua bakteri ini, oleh karena itu pada penelitian ini peneliti menggunakan ketiga agar tersebut agar dapat membedakannya lebih spesifik per media agarnya.

Tabel 4. Hasil Identifikasi Mikroorganisme Berdasarkan Pertumbuhan Koloni di media Agar

\begin{tabular}{cccc}
\hline $\begin{array}{c}\text { Pertumbuhan } \\
\text { Koloni }\end{array}$ & $\begin{array}{c}\text { Agar } \\
\text { Nutrient }\end{array}$ & $\begin{array}{c}\text { Agar Mac } \\
\text { Conkey }\end{array}$ & $\begin{array}{c}\text { Agar } \\
\text { Darah }\end{array}$ \\
\hline $\begin{array}{c}\text { Bakteri Gram } \\
\text { positif }\end{array}$ & 21 & - & 23 \\
$\begin{array}{c}\text { Bakteri Gram } \\
\text { negatif }\end{array}$ & 5 & 9 & - \\
Total & $\mathbf{2 6}$ & $\mathbf{9}$ & $\mathbf{2 3}$ \\
\hline
\end{tabular}

Tabel 5 menyajikan bahwa dari 81 media agar yang digunakan, terdapat 58 media agar yang ditumbuhi oleh bakteri, dan 23 media agar yang tidak ditumbuhi baktei. Secara keseluruhan bakteri yang paling banyak tumbuh yaitu bakteri Bacillus subtilis dan bakeri ini ditemukan hampir pada seluruh bagian ruangan.

Untuk kategori ruang perawatan diambil 9 sampel yang terbagi menjadi 4 sampel pada dinding dan 5 sampel pada lantai, dan total dari media agar yang dipakai adalah 27 dari 81 media agar yang tersedia. Pada dinding terdapat 5 media agar yang tidak ditumbuhi bakteri, dan pada lantai hanya 1 media agar yang tidak ditumbuhi bakteri (Tabel 6)

Untuk kategori perabotan ruangan diambil 2 sampel dimana 1 sampel untuk pegangan pintu dan 1 sampel untuk tempat tidur, dan total media agar yang digunakan adalah 6. Pada pegangan pintu dan tempat tidur yang masing-masing terdapat 2 media agar yang tidak ditumbuhi bakteri (Tabel 7).

Tabel 5. Hasil Identifikasi Bakteri secara keseluruhan

\begin{tabular}{|c|c|c|c|}
\hline Bakteri & n & $(\%)$ & Sampel \\
\hline Bacillus subtilis & 7 & 46,55 & $\begin{array}{l}\text { Dinding, lantai, } \\
\text { pegangan pintu, } \\
\text { udara pagi, udara } \\
\text { siang, udara sore }\end{array}$ \\
\hline $\begin{array}{l}\text { Staphylococcus } \\
\text { sp. }\end{array}$ & 1 & 18,97 & $\begin{array}{l}\text { Lantai, alat } \\
\text { USG, udara } \\
\text { pagi, udara } \\
\text { siang, udara sore }\end{array}$ \\
\hline $\begin{array}{l}\text { Streptococcus } \\
\text { sp. }\end{array}$ & 6 & 10,34 & $\begin{array}{l}\text { Udara pagi, } \\
\text { udara siang, } \\
\text { tempat tidur }\end{array}$ \\
\hline $\begin{array}{l}\text { Klebsiella } \\
\text { pneumoniae }\end{array}$ & 5 & 8,62 & $\begin{array}{l}\text { Dinding, lantai, } \\
\text { udara sore }\end{array}$ \\
\hline $\begin{array}{l}\text { Enterobacter } \\
\text { aerogenes }\end{array}$ & 2 & 3,45 & Lantai \\
\hline $\begin{array}{l}\text { Serratia } \\
\text { liquefaciens }\end{array}$ & 2 & 3,45 & Udara pagi \\
\hline $\begin{array}{l}\text { Enterobacter } \\
\text { cloacea }\end{array}$ & 2 & 3,45 & Udara siang \\
\hline Proteus sp. & 2 & 3,45 & $\begin{array}{l}\text { Udara sore, dan } \\
\text { lantai }\end{array}$ \\
\hline Neisseria sp. & 1 & 1,72 & Lantai \\
\hline Total & 8 & 100 & \\
\hline
\end{tabular}

Ket: jumlah (n), persentase (\%)

Tabel 6. Hasil Identifikasi Bakteri Kategori Ruang Perawatan

\begin{tabular}{lcc}
\hline \multicolumn{1}{c}{ Bakteri } & $\mathbf{n}$ & $\mathbf{( \% )}$ \\
\hline Dinding & & \\
$\quad$ Klebsiella pneumoniae & 3 & 14,29 \\
Bacillus sp. & 4 & 19,05 \\
Lantai & & \\
$\quad$ Bacillus subtilis & 6 & 28,57 \\
Enterobacter aerogenes & 2 & 9,52 \\
Staphylococcus sp. & 2 & 9,52 \\
Klebsiella pneumoniae & 1 & 4,76 \\
Bacillus sp. & 1 & 4,76 \\
Proteus sp. & 1 & 4,76 \\
$\quad$ Neisseria sp. & 1 & 4,76 \\
Total & $\mathbf{2 1}$ & $\mathbf{1 0 0}$ \\
\hline Ket:
\end{tabular}

Ket : jumlah (n), persentase (\%) 
Tabel 7. Hasil Identifikasi Bakteri Kategori Perabotan Ruangan

\begin{tabular}{lcc}
\hline \multicolumn{1}{c}{ Bakteri } & $\mathbf{n}$ & $\mathbf{( \% )}$ \\
\hline Pegangan Pintu & & \\
$\quad$ Bacillus sp. & 2 & 66,67 \\
Tempat Tidur & & \\
$\quad$ Streptococcus $s p$. & 1 & 33,33 \\
Total & $\mathbf{3}$ & $\mathbf{1 0 0}$ \\
\hline Ket : jumlah (n), persentase $(\%)$ & &
\end{tabular}

Untuk kategori peralatan medis diambil 1 sampel pada alat USG dan total media agar yang dipakai adalah 3, dan pada 2 media agar tidak ditumbuhi bakteri (Tabel 8).

Tabel 8. Hasil Identifikasi Bakteri Kategori Peralatan Medis

\begin{tabular}{lll}
\hline \multicolumn{1}{c}{ Bakteri } & n & $(\boldsymbol{\%})$ \\
\hline Alat USG & & \\
Staphylococcus sp. & 2 & 100 \\
Total & $\mathbf{2}$ & $\mathbf{1 0 0}$ \\
\hline
\end{tabular}

Ket : jumlah (n), persentase (\%)

Tabel 9. Hasil Identifikasi Bakteri Kategori Udara

\begin{tabular}{|c|c|c|}
\hline Bakteri & $\bar{n}$ & $(\%)$ \\
\hline \multicolumn{3}{|l|}{ Udara Pagi } \\
\hline Streptococcus sp. & 4 & 12,50 \\
\hline Bacillus sp. & 3 & 9,38 \\
\hline Staphylococcus sp. & 2 & 6,25 \\
\hline Serratia liquefaciens & 2 & 6,25 \\
\hline \multicolumn{3}{|l|}{ Udara Siang } \\
\hline Bacillus sp. & 5 & 15,63 \\
\hline Staphylococcus sp. & 2 & 6,25 \\
\hline Enterobacter cloacea & 2 & 6,25 \\
\hline Streptococcus sp. & 1 & 3,13 \\
\hline \multicolumn{3}{|l|}{ Udara Sore } \\
\hline Bacillus sp. & 6 & 18,76 \\
\hline Staphylococcus sp. & 3 & 9,38 \\
\hline Klebsiella pneumoniae & 1 & 3,13 \\
\hline Proteus sp. & 1 & 3,13 \\
\hline Total & 33 & 100 \\
\hline
\end{tabular}

Ket : jumlah (n), persentase (\%)

Tabel 9 menyatakan bahwa untuk kategori udara diambil 15 sampel masingmasing 5 sampel pada udara pagi, 5 sampel pada udara siang, dan 5 sampel pada udara sore, dan total media agar yang dipakai adalah 45. Pada udara pagi, siang, dan sore masing-masing terdapat 1 media agar yang tidak ditumbuhi bakteri,. Untuk sampel udara pagi diambil pada jam 8 sampai jam 10 pagi, kemudian udara siang diambil pada jam 1 siang sampai jam 3 sore, dan untuk udara sore diambil pada jam 4 sampai jam 6 sore.

\section{BAHASAN}

Pada ruangan Instalasi Rawat Darurat Obstetri dan Ginekologi ventilasi udaranya menggunakan Air Condittioning (AC) dan ruangannya tertutup, begitu juga dengan tempat penelitian yang saya lakukan dimana pada ruang rawat darurat ginekologi 1 merupakan ruangan yang tertutup namun bisa mendapatkan sinar matahari melalui jendela. Ventilasi udara dari ruangan ini juga menggunakan AC. Perawatan di ruangan ini biasanya satu sampai satu setengah jam. Pada waktu penelitian, ruang rawat darurat ginekologi 1 didatangi oleh banyak pasien, sehingga banyak bakteri kontaminan yang tumbuh pada media agar, dan bakteri-bakteri tersebut jika dia berada terus menerus dan hidup diluar ambang batas normalnya maka bakteri ini dapat menjadi patogen dan mengkontaminasi orang-orang yang ada disekitarnya, sehingga menyebabkan infeksi nosokomial.

Bacillus sp. dan Staphylococcus sp. adalah bakteri yang paling banyak ditemukan yaitu masing-masing sebanyak 27 media agar (46,55\%) dan 11 media agar (18,97\%), disusul oleh Streptococcus sp. 6 media agar (10,34\%), Klebsiella pneumoniae 5 media agar $(8,62 \%)$, Bacillus sp. 3 media agar $(5,17 \%)$, Enterobacter aerogenes 2 media agar (3,45\%), Serratia liquefaciens 2 media agar $(3,45 \%)$ Enterobacter cloacea 2 media agar $(3,45 \%)$, Proteus sp. 2 media agar $(3,45 \%)$, dan Neisseria sp. 1 media agar $(1,72 \%)$.

Bacillus sp. adalah bakteri Gram positif berbentuk batang, yang umumnya ditemukan di tanah, kompos tanaman, dan udara. Bacillus sp. merupakan bakteri yang paling banyak tumbuh dalam media agar 
pada penelitian ini dengan jumlah 27 media agar $(46,55 \%)$, dimana hampir seluruh bagian ruangan media agarnya ditumbuhi oleh bakteri ini. Sampel yang ditumbuhi bakteri ini yaitu dinding, lantai, pegangan pintu, udara pagi, udara siang, dan udara sore, hal ini disebabkan karena bakteri ini dapat beradaptasi pada perubahan suhu lingkungan ekstrim dengan membentuk endospora. Bakteri ini bersifat mesofilik non-patogenik, tapi bisa mencemari makanan namun jarang menyebabkan keracunan makanan. ${ }^{11,12}$ Penelitian ini berhubungan dengan penelitian yang dilakukan pada kamar bersalin RSUP Prof. Dr. R. D. Kandou Manado, dimana bakteri yang paling banyak ditemukan adalah bakteri Bacillus subtilis dimana ini merupakan salah satu spesies dari Bacillus $s p$. yang ditemukan sebanyak 15 sampel yang berasal dari dinding, lantai, tempat tidur, udara, serta selang dan tabung oksigen. ${ }^{9}$

Staphylococcus sp. adalah bakteri kedua terbanyak yang ditemukan dalam penelitian ini. Bakteri ini tumbuh sebanyak 11 media agar $(18,97 \%)$, pada sampel lantai, alat USG, udara pagi, udara siang, dan udara sore. Staphylococcus sp. terdapat dalam jumlah besar di kulit dan selaput lendir manusia, dan bakteri ini juga merupakan penyebab infeksi utama dari alat plastik yang dimasukkan ke tubuh manusia misalnya pirau (shunt) serebrospinal, kateter vena sentral, kateter dialisis peritoneal, kateter saluran kemih dan berbagai polimer serta logam implan lainnya. ${ }^{13}$ Pernyataan ini berkorelasi dengan hasil penelitian saya dimana bakteri ini ditemukan pada alat USG yang berbahan dasar polimer. Penelitian ini juga berhubungan dengan penelitian yang dilakukan di ruang bedah saraf Rumah Sakit Daerah Dr. Abdul Moeloek pada tahun 2009, bakteri yang ditemukan pada sampel udara adalah Staphylococcus aureus, Staphylococcus epidermidis, Staphylococcus sapropthycus, Streptococcus sp., Salmonella sp., dan Shigella $s p{ }^{14}$ dimana Staphylococcus aureus, Staphylococcus epidermidis,
Staphylococcus sapropthycus merupakan spesises dari Staphylococcus sp.

Streptococcus sp. merupakan bakteri Gram positif dan merupakan famili Streptococcaceae. ${ }^{15}$ Bakteri ini tumbuh pada 6 media agar $(10,34 \%)$ pada sampel udara pagi, udara siang, dan tempat tidur. Streptococcus sp. hidup komensal di traktus respiratorius atas manusia, traktus gastrointestinal, dan traktus genitalis wanita. ${ }^{16}$ Beberapa infeksi yang disebabkan oleh Sterptococcus $s p$. adalah faringitis, endokarditis, selulitis, pneumonis, dan lainlain. ${ }^{16}$ Ditemukannya bakteri ini diakibatkan karena pada sampel tempat tidur dilakukan pengambilan sampel pada bagian tempat tidur ginekologi yang memiliki lubang di daerah genitalia wanita jika pasien berbaring diatasnya.

Klebsiella pneumoniae adalah Gram negatif yang banyak ditemukan di mulut, kulit, saluran usus, dan udara, namun habitat alami dari bakteri ini adalah di tanah. Bakteri ini terdapat pada saluran napas dan feses pada sekitar 5\% individu normal, dan bakteri ini juga dapat menyebabkan infeksi nosokomial. ${ }^{17}$ Hasil penelitian pola kuman di ICU RS Dr. Wahidin Sudirohusodo Makassar tahun 2009, ditemukan bahwa Klebsiella pneumoniae adalah kuman terbanyak di udara (28,3\%), sedangkan Pseudomonas aeroginosa dan Alkaligenes faecalis masing-masing hanya sebanyak $3,3 \%{ }^{8}$ Berbeda dengan penelitian ini, Klebsiella pneumoniae merupakan bakteri keempat terbanyak yang ditemukan pada 5 media agar $(8,62 \%)$ yang terdapat pada sampel dinding, lantai dan udara sore. Perbedaan pada hasil penelitian ini karena adanya perbedaan tempat dimana pada ruang ICU banyak pasien yang sudah lama dirawat dan menggunakan alat bantu nafas sehingga dapat berkembanglah Klebsiella pneumoniae, sedangkan pada tempat penelitian saya jarang pasien yang datang dan menggunakan alat bantu nafas kemudian menjalani perawatan yang lama diruangan.

Enterobcter aerogenes, Serratia liquefaciens, Enterobacter cloacea, dan 
Proteus sp. bakteri ini tumbuh masingmasing pada 2 media agar $(3,45 \%)$ dan masing-masing juga ditemukan pada sampel lantai, udara pagi, udara siang, dan untuk Proteus sp. ditemukan di udara sore dan lantai. Enterobcter aerogenes termasuk dalam Enterobcteriaceae. Bakteri ini berada dalam tanah, air, dan produk susu, dan dapat mengakibatkan infeksi pada saluran pernapasan, gastrointestinal, dan saluran kemih. Sebagian besar dari infeksi tersebut disebabkan akibat perpindahan bakteri selama operasi atau perawatan yang lama di rumah sakit pada pasien yang menggunakan infus atau kateter. ${ }^{18}$ Pada penelitian yang dilakukan di ruang rawat intensif RSUP Dr. Kariadi periode Juli Desember 2009 tersebut dapat ditemukan bahwa kuman terbanyak penyebab infeksi adalah Enterobacter aerogenes (34\%), Staphylococcus epidermidis (17\%), Escherichia coli (15\%), Pseudomonas aeruginosa (10\%), Candida spp. (9\%), dan Acinetobacter spp. (8\%). ${ }^{8}$ Serratia liquefaciens adalah bakteri Gram negatif berbentuk batang, ditemukan di permukaan tanah, air, dan tanaman, dan bakteri ini termasuk dalam famili Enterobacteriaceae. Bakteri ini merupakan bakteri patogen oportunistik dan dapat menyebabkan infeksi termasuk bakteremia, pneumonia, dan gastroenteritis. Saat ini, Serratia liquefaciens dikaitkan dengan infeksi nosokomial. ${ }^{18}$ Pada penelitian yang dilakukan di kamar bersalin RSAD Robert Wolter Moginsidi Manado, ditemukan Serratia liquefaciens pada 1 sampel (4\%) yaitu pada lantai. ${ }^{10}$ Enterobacter cloacea adalah bakteri Gram negatif yang termasuk dalam famili Enterobacteriaciae, sering ditemukan di tanah, limbah, air, dan makanan. Spesies ini merupakan flora normal di dalam usus manusia. ${ }^{19}$ Bakteri ini juga sering ditemukan di rumah sakit karena bersifat resisten terhadap desinfektan dan ditemukan merupakan penyebab penting infeksi nosokomial. ${ }^{20}$ Enterobacter cloacea sering dikaitkan dengan kontaminasi pada cairan IV, alatalat postetik, dan alat operasi. Namun, pada penelitian ini justru ditemukan pada sampel udara siang. Proteus sp. adalah bakteri batang Gram negatif, bakteri ini dapat menimbulkan infeksi pada manusia hanya bila bakteri keluar dari saluran cerna. Organisme ini ditemukan pada infeksi saluran kemih dan menimbulkan bakteremia, pneumonia, dan infeksi fokal pada pasien yang lemah atau pada pasien menerima infus intravena. ${ }^{17}$

Neisseria sp. adalah bakteri kokus Gram negatif yang biasanya muncul berpasangan. Beberapa Neisseria sp. merupakan flora normal saluran napas manusia, jarang menyebabkan penyakit, dan timbul secara ekstraselullar. ${ }^{21}$ Berdasarkan penelitian yang dilakukan di RSUD Dr. Abdul Moeloek pada inkubator bayi unit perinatalogi ditemukan bakteri Neisseria sp. merupakan bakteri di udara yang paling banyak (55\%). ${ }^{14}$ Hal ini berbeda dengan penelitian ini karena pada peneltian ini bakteri tersebut hanya tumbuh pada satu media agar dan ditemukan pada sampel lantai.

Pada kategori ruang perawatan pada dinding ditemukan Bacillus sp, dan Klebsiella pneumoniae. Dari 12 media agar ditemukan Klebsiella pneumoniae sebanyak 3 media agar (14,28\%). Ditemukanya bakteri ini mungkin karena banyak tanda kotoran alas kaki pada sampel dinding yang saya swab yang mungkin alas kakinya terkontaminasi dengan dunia luar. Pada sampel lantai ditemukan Bacillus sp., Enterobacter aerogenes, Staphylococcus sp., Klebsiella pneumoniae, Proteus sp., Neisseria sp. Pada sampel lantai yang paling banyak ditemukan adalah bakteri Bacillus sp. Organisme ini lazim terdapat dalam tanah, air, udara, serta tumbuh-tumbuhan, ${ }^{18}$ dan kemungkinan bakteri ini ditemukan pada lantai yaitu melalui alas kaki yang sudah terkontaminasi dengan dunia luar, atau lewat air pel yang kurang mengandung cairan antiseptik dan sapu yang digunakan pada ruangan tersebut.

Pada kedua sampel di atas ditemukan Bacillus sp. dan Klebsiella pneumoniae dimana bakteri ini juga ditemukan di ruang perawatan Neonatal Intensive Care Unit 
(NICU) di RSUP Prof. Dr. R. D. Kandou Manado, namun di NICU juga ditemukan bakteri Serratia liquefaciens dan Bacillus subtilis yang merupakan salah satu spesies dari Bacillus sp. Hal ini dapat disebabkan oleh karena perbedaan jenis penyakit dan usia pasien yang dirawat. ${ }^{22}$

Berdasarkan pedoman teknis PPI tahun 2011, konstruksi rumah sakit untuk dinding harus dibuat kuat, rata, dan kedap air sehingga mudah dibersihkan secara periodik dengan jadwal yang tetap 3-6 bulan sekali. Cat dinding berwarna terang dan menggunakan cat yang tidak luntur sert tidak mengandug logam berat. Sedangkan untuk lantai harus terbuat dari bahan yang kuat, halus, kedap air, tidak licin, warna terang, permukaan rata, tidak bergelombang sehingga mudah dibersihkan secara rutin 3 kali sehari atau kalau perlu. Pertemuan lantai dengan dinding harus berbentuk lengkung agar mudah dibersihkan. $^{23}$ Larutan antiseptik lantai yang ideal untuk digunakan yaitu jangka panjang, bekerja cepat dalam membunuh kuman, tidak toksik, tidak terpengaruh oleh faktor lingkungan, mudah digunakan dengan cara penggunaan yang jelas, tanpa bau, ekonomis, membersihkan dengan baik, dan ramah lingkungan. ${ }^{24}$

Berdasarkan penjelasan di atas maka sebaiknya pihak rumah sakit lebih berusaha memperhatikan dan menigkatkan hygiene dan kebersihan ruangan, selain rutin dibersihkan kalau misalnya sudah kelihatan berdebu langsung di bersihkan, dan untuk cairan pembersih lantai harus yang mengandung antiseptik, karena mengingat bahwa ruang rawat darurat merupakan tempat penanganan pertama pada pasien dan seperti yang telah dijelaskan bahwa orang yang masuk ke dalam ruangan ini tidak mengganti alas kaki, sehingga banyak mikroorganisme yang berasal dari tanah dapat tekontaminasi ke dalam ruangan ini.

Pada perabotan ruangan yang diambil sampel pada tempat tidur dan pegangan pintu masing-masing ditemukan Streptococcus sp. dan Bacillus sp. Bakteri yang ditemukan pada perabotan ruangan semuanya bakteri Gram positif. Penelitian ini berbeda dengan penelitian yang dilakukan di kamar bersalin RSAD Robert Wolter Monginsidi Manado, yang mengambil 4 sampel tempat tidur dan ditemukan bakteri Enterobacter aglomerans, Lactobacillus sp., dan Staphylococcus epidermidis. ${ }^{10}$ Perbedaan dari hasil penelitian ini karena mungkin pada penelitian saya hanya diambil satu sampel saja jadi bakteri yang tumbuh tidak banyak dan bervariasi. Tumbuhnya bakteribakteri tersebut pada tempat tidur mungkin karena tempat tidur tidak dibersihkan setelah digunakan oleh pasien, oleh karena itu sebaiknya dibersihkan setelah digunakan.

Pada peralatan medis dimana sampel yang diambil yaitu alat USG ditemukan bakteri Staphylococcus sp. pada 2 media agar $(66,67 \%)$. Dalam studi beberapa tahun terakhir bahwa Staphylococcus epidermidis yang merupakan spesies dari Staphylococcus sp. telah menunjukkan kemampuan bakteri ini dapat menebal, membentuk biofilm berlapis pada permukaan yang lembap seperti polimer atau logam merupakan ciri khas hasil isolasi nosokomial bakteri ini, dan studi ini menyarankan bahwa berbagai peralatan medis seperti infus, oxygen set, stetoskop, alat USG serta peralatan medis lainnya yang berbahan polimer dan logam perlu diwaspadai akan pertumbuhan patogen dari bakteri ini. ${ }^{25}$ Pertumbuhan bakteri ini pada alat USG kemungkinan karena bakteri ini merupaka flora normal kulit sehingga dapat ditemukan, karena sebelum alat USG ini digunakan tidak dilakukan tindakan sterilisasi terlebih dahulu.

Untuk kategori udara pertumbuhan bakterinya berbeda yaitu, pada udara pagi ditemukan bakteri Streptococcus sp., Bacillus sp., Staphylococcus sp., Serratia liquefaciens. Pada udara siang ditemukan Bacillus sp., Staphylococcus sp., Enterobacter cloacea, Streptococcus sp., dan pada udara sore ditemukan Bacillus sp., Staphylococcus sp., Klebsiella pneumoniae dan Proteus sp. Penelitian ini sedikit berbeda dengan hasil penelitian yang dilakukan di Instalasi Rawat Khusus 
RSUP Dr. Wahidin Sudirohusodo Makassar mengenai pola kuman yang terdapat di Intensive Care Unit (ICU), dengan sampel udara ruang yang diambil pada satu titik di Operatie Kamer Central Operating Theatre (OK COT), Operatie Kamer Instalasi Rawat Darurat (OK IRD), dan lima titik di Intensive Care Unit (ICU), ditemukan Staphylococcus epidermidis (40\%), Acinobacter calcoaceticus (20\%), Alkaligens faecalis (10\%), Staphylococcus aureus (10\%), Staphylococcus sapropiticus $(10 \%)$, dan Bacillus subtilis $(10 \%) .^{8}$ Pada penelitian yang saya lakukan Staphylococcus sp. merupakan bakteri yang paling banyak ditemukan di udara dan hal ini berhubungan dengan hasil penelitian tersebut dimana Staphylococcus epidermidis merupakan bakteri yang paling banyak ditemukan di udara dan bakteri ini merupakan spesies dari Staphylococcus sp. Konsentrasi maksimum mikroorganisme di rumah sakit berdasarkan keputusan menteri kesehatan Republik Indonesia nomor 1204/Menkes/SK/X/2004 tentang persyaratan kesehatan lingkungan rumah sakit dimana untuk rawat darurat konsentrasi maksimum mikroorganisme per $\mathrm{m}^{3}$ udara yaitu $200 \mathrm{CFU} / \mathrm{m}^{3}{ }^{26}$ Kualitas udara ruang rumah sakit yang tidak memenuhi persyaratan kesehatan dapat menimbulkan gangguan kesehatan terhadap pasien, tenaga yang bekerja di rumah sakit, serta pengunjung rumah sakit. ${ }^{27}$ selain itu, bakteri di udara juga dipengaruhi oleh kepadatan ruangan atau jumlah orang yang ada dalam ruangan, karena penyebaran penyakit dalam ruangan yang padat penghuninya akan lebih cepat jika dibandingkan dengan ruangan yang jarang penghuninya. ${ }^{28}$ Pertumbuhan bakteri pada sampel udara di ruangan ini mungkin karena ventilasi udaranya kurang baik, karena seperti yang telah dijelaskan bahwa ruangan ini tertutup dan menggunakan Air Condittioning (AC), oleh karena itu pihak rumah sakit bisa lebih memperhatikan pembersihan dan perawatannya, atau bisa juga menggunakan Air Condittioning (AC) yang sudah ada anti bakterinya.

\section{SIMPULAN}

Dari hasil penelitian tentang pola bakteri aerob berpotensi menyebabkan infeksi nosokomial di ruang Instalasi Rawat Darurat Obstetri dan Ginekologi (IRDO) RSUP Prof. Dr. R. D. Kandou Manado, dapat disimpulkan bahwa Jumlah pertumbuhan bakteri Gram positif lebih banyak dari Gram negatif, dan Bacillus sp. merupakan bakteri terbanyak yang ditemukan.

\section{DAFTAR PUSTAKA}

1. Septiari BB. Rumah Sakit. In: Infeksi Nosokomial. Edisi ke-1. Yogyakarta: Nuha Medika; 2012. H. 1-18.

2. Erfavira A. Perbedaan Kelengkapan Pengisian Rekam Medis Antara Instalasi Rawat Jalan dan Instalasi Rawat Darurat di Poli Bedah RSUP Dr. Kariadi Semarang [Karya Tulis Ilmiah]. [Semarang]: Fakultas Kedokteran Unversitas Diponegoro; 2012.

3. Prawirohardjo S, Wknjosastro H. Kebidanan Dalam Masa Lampau Masa Kini dan Kelak. In: Saifuddin AB, Rachimhadhi T, Wiknjosastro H, Editor. Ilmu Kebidanan. Edisi ke-4. Jakarta: PT Bina Pustaka Sarwono Prawirohardjo; 2014. h. 3.

4. Anies. Manajemen Berbasis Lingkungan. Jakarta, Gramedia, 2006

5. Nungraheni R, Suhartono, Winarni $S$. Infeksi Nosokomial di RSUD Setjonegoro Kabupaten Wonosobo. Media Kesehatan Mayarakat Indonesia. 2012;11:94-100.

6. Widodo D, Irwanto R. Infeksi Nosokomial. In: Setiati S, Alwi I, Sudoyo AW, Simadibrata M, Setiyohadi B, Syam AF, Editor. Buku Ajar Penyakit Dalam. Edisi ke-6. Jakarta: Interna Publishing; 2014. H. 682-91.

7. WHO. 2011. HAIs Surveilance. http://www.who.int/ bulletin/volumes/89/ 10/11088179/en/ (Cited tanggal 13 November 2016).

8. Taslim E, Maskoen TT. Pola Kuman Terbanyak Sebagai Agen Penyebab Infeksi di Intensive Care Unit Pada Beberapa Rumah Sakit di Indonesia. Anasthesia \& Critical Care. 2016;34:56-62. 
9. Kambey G, Homenta H, Porotu'o J. Pola Bakteri Aerob Yang Berpotensi Menyebabkan Infeksi Nosokomial di Kamar Bersalin RSUP Prof. Dr. R. D. Kandou Manado. eBm. 2016;4:1-5.

10. Ritto LE. Pola Bakteri Aerob Yang Menyebabkan Infeksi Nosokomial Pada Kamar Bersalin RSAD Robert Wolter Monginsidi Manado [Karya Tulis Ilmiah]. [Manado]: Universitas Sam Ratulangi; 2016

11. Rahmaningsih S, Wlis $\mathrm{S}$, Mulyana A. Ekologia, Vol. 12 No.1, April 2012:15.

12. Mardaneh, Jalal, Dallal, Soltan M. M. Isolation, identification and antimicrobial susceptibility of pantoea (Enterobacter) agglomerans isolated from consumed powdered infant formula milk (PIF) in NICU ward: First report form Iran. Iranian journal of microbiology, 2013, 5.3:263. [Citied 2015 Jan22].Availablefrom http://ijm.tums.ac.ir/index.php/ijm/art icle/viewfile/745/343.

13. Elliot T, Worthington T, Osman H, Gill M. Stafilokokus. In: Puspadewi N, Suyono YJ, Djayasaputra L, Editor. Mikrobiologi Kedokteran dan Infeksi. Edisi ke-4. Jakarta: EGC; 2009. H. 23-27.

14. Imaniar E, Apriliana E, Rukmono P. Kualitas Mikrobiologi Udara di Inkubator Perinatalogi Rumah Sakit Umum Daerah Dr. Abdul Moeloek Bandar Lampung. MAJORITY. 2012: 51-60.

15. Joshi R, Reingold AL, Menzies D, Pai M. Tuberculosis among health care workers in low- and middle-income countries: A systemic review. PloS Med 3(12): e494. Doi:10.1371/journal.pmed.0030494.2 006.

16. Elliot T, Worthington T, Osman H, Gill M. Streptokokus dan Enterokokus. In: Puspadewi N, Suyono YJ, Djayasaputra L, Editor. Mikrobiologi Kedokteran dan Infeksi. Edisi ke-4. Jakarta: EGC; 2009. H. 29-34.

17. Jawetz, Melnikk, dan Adelberg's, Brooks GF, Butel JS, Morse SA. Batang Gram Negatif Enterik
(Enterobacteriaceae). In: Elfria RN, Ramadhani D, Kandina S, Indriyani F, Rianti SSP, Yulia P, Editor. Mikrobiologi Kedokteran. Edisi ke23. Jakarta: EGC; 2004. H. 255-7.

18. Jawetz, Melnick, Adelberg. Mikrobiologi Kedokteran Ed 23. Jakarta Penerbit Buku Kedokteran EGC, 2007.

19. Regli AD, Pages JM. Enterobacter aerogenes and Enterobacter cloacea; versatile bacterial pathogens conforting antibiotic teratement. Front Microbiol.2015;6:1-10.

20. ButikoferS, Dettori JM, Vemulakonda GA, Salbaugh M. Enterobacter cloacea postsurgical endophthalmitis: report of a positive outcome. Case Rep Ophtalmol.2013;4:42-5.

21. Jawetz, Melnikk, dan Adelberg's, Brooks GF, Butel JS, Morse SA. Neisseriae. In: Elfria RN, Ramadhani D, Kandina S, Indriyani F, Rianti SSP, Yulia P, Editor. Mikrobiologi Kedokteran. Edisi ke-23. Jakarta: EGC; 2004. H. 300.

22. Saleh M, Rares FES, Soeliongan S. Pola bakteri aerob penyebab infeksi nosokomial pada ruangan Neonatal Intensive Care Unit (NICU) BLU RSUP Prof. Dr. R. D. Kandou Manado. [skripsi]. [Manado]: Universitas Sam Ratulangi Manado;2015.

23. Nasution $C R$, Arinie $C P$, Hermawan $S$, Lebang Y, Giriputro S, Setiabudi D, et al. Pelaksanaan Pencegahan dan Pengendalian Infeksi di Rumah Sakit dan Fasilitas Pelayanan Kesehatan Lainnya. In: Sulistomo A, Bimo, Kaslam P, Adisasmito AW, Astrawinata D AW,Azoeddin F editors. Pedoman Pencegahan Pengendalian Infeksi di Rumah Sakit dan Fasilitas Kesehatan Lainnya. Edisi ke-3. Jakarta: Kementrian Kesehatan RI; 2011.

24. Environmental Disinfection Choice of disinfectant performance evaluation. Korean Society for Laboratory Medicine Spring Symposium; 2014 April 5; W Seoul Walkerhill Hotel.

25. Ziebuhr I, Hennig S, Eckart $M$, Kranzler H, Batzilla C, Kozitskaya S. Nosocomial and community- 
acquired Enterobacter cloacea bloodstream infection: risk factors for and prevalance of SHV-12 in multiresistant isolates in a medical center. The Journal of Hospital Infection. 2004;58-63-77.

26. Keputusan Menteri Kesehatan Republik Indonesia Nomor 1204/Menkes/SK/X/2004 tentang persyaratan kesehatan lingkungan rumah sakit. 2004:6-7.
27. Keputusan Menteri Kesehatan Republik Indonesia Nomor 1335/Menkes/SK/X/2002 tentang Standar operasional pengambilan dan pengukuran sampel kualitas udara ruangan rumah sakit. 2002: 1:20-21.

28. Oktariani M. Angka dan pola kuman pada dinding, lantai, dan udara di ruang ICU RSUD Dr. Moewardi Surakarta. [skripsi]. [Surakarta]: Universitas Muhammadiyah Surakarta; 2013. 